\title{
Aflatoxin and Fumonisin in Corn (Zea mays) Infected by Common Smut Ustilago maydis
}

Hamed K. Abbas, Biological Control of Pests Research Unit, and Robert M. Zablotowicz, Crop Production Systems Research Unit, United States Department of Agriculture-Agricultural Research Service (USDA-ARS), Stoneville, MS 38776; W. Thomas Shier, Department of Medicinal Chemistry, College of Pharmacy, University of Minnesota, Minneapolis 55455; Bobbie J. Johnson, Nicholas A. Phillips, and Mark A. Weaver, Biological Control of Pests Research Unit, USDA-ARS; Craig A. Abel, Corn Insect and Crop Genetics Research Unit, USDA-ARS, Iowa State University, Ames 50010; and H. Arnold Bruns, Crop Production Systems Research Unit, USDA-ARS

\begin{abstract}
Abbas, H. K., Zablotowicz, R. M., Shier, W. T., Johnson, B. J., Phillips, N. A., Weaver, M. A., Abel, C. A., and Bruns, H. A. 2015. Aflatoxin and fumonisin in corn (Zea mays) infected by common smut Ustilago maydis. Plant Dis. 99:1236-1240.

Corn infected with Ustilago maydis (common smut) produces galls that are valued as a delicacy in some cultures. During a 4-year period, aflatoxin levels in asymptomatic kernels of smutted ears were, on average, 45-fold higher than in kernels harvested from smut-free control ears and 99-fold higher than in smut galls. Aflatoxin levels in smut galls were lower than in kernels of smut-free control corn in all years combined. Fumonisin levels in asymptomatic kernels harvested from smutted ears

were 5.2-fold higher than in kernels from smut-free control ears and 4.0-fold higher than in smut galls. Fumonisin levels in smut galls were not significantly different than in kernels of smut-free control corn. These studies indicate that, although corn smut was relatively free of the mycotoxins studied, the asymptomatic kernels of those ears contained mycotoxins at levels much higher than usually considered safe for direct human consumption.
\end{abstract}

Common smut caused by Ustilago maydis (25) occurs frequently in corn-growing areas in the United States, including the Mississippi Delta. The fungus causes the formation of structures called galls that are filled with black teliospores. These galls are considered a delicacy in certain parts of the world, particularly in Mexico, and are marketed as "corn truffle", "maize mushroom", "huitlacoche", and "cuitlachoche" (27). In those regions, smut galls are valued at about three times the normal corn crop; thus, farmers encourage smut formation by loosening corn husks in the field.

Generally, $U$. maydis is not deleterious to corn productivity and profitability in the United States $(7,25)$. However, other fungi, which may infect corn by similar routes, do impact productivity and profitability if they produce mycotoxins that contaminate corn kernels. Mycotoxin (particularly aflatoxin and fumonisin) contamination of corn is a serious food safety concern causing economic losses and is a major limitation for corn production (23). Aflatoxin is more frequently a problem in the southern United States, while fumonisin can be a problem in both the Midwest and the South. The accumulation of aflatoxin in corn is influenced significantly by several environmental factors such as drought, heat stress, insects, and plant disease $(2,4,8,9,13,21)$. A wider range of environmental parameters, including warm and wet conditions, insects, corn genotypes, and plant diseases, influence fumonisin accumulation in corn $(2,4,8,9)$. Coexistence of both toxins in corn increases toxicological concerns $(3,12,16,19)$.

Little is known about the relationship between infection with $U$. maydis and mycotoxin contamination in corn. In one study

Corresponding author: H. K. Abbas, E-mail: hamed.abbas@ars.usda.gov

Disclaimer: Trade names are used in this publication solely for the purpose of providing specific information. Mention of a trade name, propriety product, or specific equipment does not constitute a guarantee or warranty by the USDAARS and does not imply approval of the named product to exclusion of other similar products.

Accepted for publication 14 February 2015.

http://dx.doi.org/10.1094/PDIS-03-14-0234-RE

This article is in the public domain and not copyrightable. It may be freely reprinted with customary crediting of the source. The American Phytopathological Society, 2015. evaluating fungal populations and mycotoxins in silage, silage made from smut-infected corn had increased mold and yeast (22). Aflatoxin was not detected in silage, while concentrations of other mycotoxins, including deoxynivalenol, ochratoxin, and zearalenone, were low and did not change during ensiling.

Formation of smut galls on corn ears disrupts the husks and provides other fungi with an infection route to exposed, unsmutted kernels. In view of the limited understanding of the effect of common smut infection on plant stress in corn and on other factors that could contribute to infection by Aspergillus spp. and other fungi and to production of aflatoxin and fumonisin in corn, field studies were conducted in 2006, 2007, 2008, and 2009 in Mississippi to evaluate the incidence of common smut and its effect on (i) colonization of grain by Aspergillus flavus and (ii) aflatoxin and fumonisin levels in a Bt (34B24Bt) and a near-isogenic non-Bt (34B23) hybrid. Bt transgenic corn hybrids express Bacillus thuringiensis Cry insecticidal proteins that confer resistance to some ear-feeding insects and, thus, may reduce mycotoxins associated with insect-vectored fungal contamination (14).

\section{Materials and Methods}

Field trial experimental design. Experiments were conducted at the Southern Insect Management Research Unit Experimental farm at Elizabeth, MS, in 2006, 2007, 2008, and 2009. The study was conducted in corn planted for a study comparing mycotoxin and A. flavus levels in aging $\mathrm{Bt}$ and non-Bt corn residues under conventional till and Mississippi no-till conditions, which is described in detail by Abbas et al. (1). Briefly, the experimental design in the field was a randomized complete block design replicated in five blocks with corn hybrids 34B24 and 34B24Bt. The same treatment occurred on the same plots in each year of the study, except that in 2008 and 2009 , the study was expanded to include a comparison of conventional till and Mississippi no-till conditions in a two-by-two randomized complete block design. The field had been planted in cotton for several years previously; therefore, it had no recent history of corn smut but it had a history of high incidences of Fusarium verticillioides and A. flavus (1). Because there is a high degree of variability in aflatoxin production in crops, the study used large plots $\left(100 \mathrm{ft}^{2}\right.$, 30.5 by $30.5 \mathrm{~m}, 32$ rows in each plot, with soybean planted in a 30.5-m buffer area between plots) and large sample sizes (1). Natural infection by $U$. maydis was relied on and husks were not opened. 
It was not determined whether the source of $U$. maydis was long-term survival in field soil or transmission from remote sources.

Disease rating. Each block was divided into three sections of 10 rows each. The incidence of common smut-infected ears was counted at maturity on 100 plants from the middle two rows of each plot. Corn ears were considered infected with common smut only when one gall or more was visible to the naked eye. The percentage of common smut was recorded for each block based on an average of three sections per block. Aspergillus ear rot was not assessed.

Experimental parameters. Corn was hand harvested at maturity (moisture content at $20 \%$ or less; 40 ears with smut galls per section and 40 ears with no visible smut galls per section) using several large paper bags $(5 \mathrm{~kg})$ for each sample. All samples were dried at $50^{\circ} \mathrm{C}$ in a forced air drier for 3 to 5 days to $\leq 12 \%$ moisture content. When high levels of aflatoxins in asymptomatic kernels of smutted ears were first observed in 2006, all field samples had been divided into two groups: (i) smutted ears from which common smut galls were removed by hand and (ii) ears with no visible smut galls. In 2007, 2008, and 2009, the scope of the study was expanded by dividing all field samples into three groups: (i) asymptomatic kernels from smutted ears from which common smut galls were removed by hand, (ii) apparently noninfected ears (ears with no visible smut galls), and (iii) common smut galls (teliospores). Variability in A. flavus infestation and aflatoxin production was addressed by taking large samples totaling at least $2 \mathrm{~kg}$ after shelling and using triplicate subsamples of ground kernels for chemical and biological determinations. The harvested, dried corn ears without galls were shelled, mixed, and ground in a Romer mill (20 mesh; Union, MO) before aflatoxin and fumonisin analysis and quantification of $A$. flavus. Galls of common smut were initially crushed with a hammer between two layers of paper, passed through a 2-mm sieve to remove any plant tissues, and ground to a fine powder in a coffee grinder individually to avoid cross contamination. Subsamples were taken for mycotoxin and fungal determination. Insect damage to corn was not assessed.

A. flavus isolation. A. flavus was isolated from ground samples of asymptomatic kernels from smutted ears with the galls removed, kernels from apparently noninfected corn ears, and gall samples (described above) on modified dichloronitroaniline rose Bengal media (mDRBA) (5) supplemented with $3 \% \mathrm{NaCl}$. Field sample material $(1 \mathrm{~g})$ was added to $100 \mathrm{ml}$ of $0.2 \%$ water agar and shaken on an Eberbach shaker for $30 \mathrm{~min}$. The samples were serially diluted, and four replications per sample were plated on mDRBA plates and incubated for 5 days at $37^{\circ} \mathrm{C}$.

Aflatoxin analysis. Total aflatoxin concentrations were analyzed by high-performance liquid chromatography (HPLC) with confirmation in some years by enzyme-linked immunosorbent assay using commercially available kits (Neogen Inc., Lansing, MI) according to the manufacturer's instructions. Shelled kernels or smut galls from each plot were pooled and ground, then oven dried at $50^{\circ} \mathrm{C}$ for 3 to 5 days. A representative subsample (10 g of sample for smut galls and $20 \mathrm{~g}$ of sample for kernels) was taken from each plot sample and extracted in $100 \mathrm{ml}$ of $70 \%$ methanol, as previously described by Abbas et al. $(1,2)$. Sample cleanup was carried out by diluting $500 \mu \mathrm{l}$ of sample extract with $500 \mu \mathrm{l}$ of acetonitrile in a microcentrifuge tube. The diluted aliquot was mixed on a vortex mixer, and $800 \mu \mathrm{l}$ of the mixture was then applied to a 1.5 -ml extract-clean reservoir minicolumn packed with aluminum oxide $(1,2)$. After elution from the cleanup column, $20 \mu \mathrm{l}$ of the eluate was injected onto a Waters HPLC system composed of a Waters 717 Autosampler, Waters 600 Pump, Waters 2475 Fluorescence Detector, and Waters Temperature Control Module equipped with a $4-\mu \mathrm{m}$ Nova-Pak C18 column ( 150 by $3.9 \mathrm{~mm}$ i.d.) at a column temperature of $30^{\circ} \mathrm{C}$. Detection was achieved using a Photochemical Reactor for Enhanced Detection unit purchased from Aura Industries in combination with a fluorescent detector set at $365 \mathrm{~nm}$ (excitation) and $440 \mathrm{~nm}$ (emission). The mobile phase for this system was water/methanol/1-butanol (700:360:12.5 [vol/vol/vol]) with a flow rate of $0.9 \mathrm{ml} / \mathrm{min}$. An aflatoxin standard mixture (number A9441; Sigma-Aldrich, St. Louis) and additional standard dilutions were studied using an methanol/water/acetic acid (310:190:0.5 [ $\mathrm{vol} / \mathrm{vol} / \mathrm{vol}]$ ) elutant. The same solution served as the blank during the HPLC run. The limit of detection was $0.1 \mathrm{ng} \mathrm{g}^{-1}$, and the standard curve was linear up to $200 \mathrm{ng} \mathrm{g}^{-1}$.

Fumonisin cleanup. Methanol extracts were used for fumonisin with cleanup of samples using Bond-Elute SAX columns (Varian, Harbor City, CA), as described by Abbas et al. (2). Samples were evaporated under nitrogen and stored at $5^{\circ} \mathrm{C}$ until further analysis by liquid chromatography/mass spectrometry (LC/MS). The clean sample was reconstituted in $1 \mathrm{ml}$ of acetonitrile/water (1:1). The limit of detection was $1 \mathrm{ng} \mathrm{g}^{-1}$.

LC/MS analysis of fumonisins. The analytical method used for detecting various fumonisins was LC/MS (2). Fumonisin analysis was conducted using a MetaChem Intersil 5 $\mu$ ODS-3 column eluted with water/1\% acetic acid/methanol (65:35:0) at $300 \mu l \mathrm{~min}^{-1}$ for $10 \mathrm{~min}$ followed by a linear gradient to water $1 \%$ acetic acid in methanol/methanol (5:35:65), then held constant for $10 \mathrm{~min}$. Between samples, the solvent was returned to water $/ 1 \%$ acetic acid in methanol/methanol (65:35:0) within $1 \mathrm{~min}$ and held constant for 4 min for column equilibration. Analysis was carried out using an LTQ XL linear ion trap mass spectrometer with a Surveyor pump and autosampler (Thermo Electron Corporation, West Palm Beach, FL). Quantitation of FB1 and FB2 was carried out by the external standard method (linearity range of standards was 0.99 ).

Statistical analysis. The percentage of ears with visible smut galls and A. flavus CFU were analyzed using Fisher's least significant difference (LSD) in the PROC GLM procedure in the SAS statistical package (26). Mycotoxin concentrations in field samples were analyzed using analysis of variance (ANOVA) in the Microsoft Excel 2010 statistical package. Mycotoxin concentrations in field samples within the randomized complete block design were initially analyzed using LSD values estimated with PD MIXED 800 (24).

\section{Results}

Common smut was observed in corn in the Mississippi Delta region in each of the years from 2006 to 2009 (Table 1). The greatest incidence of smut was observed in 2006, with an average of approximately $17 \%$ in both cultivars. In the subsequent 3 years of the study, the incidence of smut was lower (2.6 to $4.8 \%$ ). There was no significant effect of Bt genotype or type of tilling on the incidence of common smut, and no significant interactions.

Aflatoxin levels varied significantly from year to year but were found to be consistently much higher in the asymptomatic kernels of smutted ears than in smut galls or in the kernels of apparently uninfected ears from the same plots, which were used as controls in each of the years studied (Table 2). Total aflatoxin levels in asymptomatic kernels of smutted ears for all years combined was 45-fold higher $\left(1,970\right.$ versus $\left.43.7 \mu \mathrm{g} \mathrm{kg}^{-1}\right)$ than in kernels harvested from smut-free control ears (range $=4$ - to 1,072-fold higher; ANOVA, $P<0.001)$. The total aflatoxin level in asymptomatic kernels of smutted ears for all years combined was 99-fold higher (range $=78$ - to 476-fold higher) than in smut galls $\left(1,970\right.$ versus $19.9 \mu \mathrm{g} \mathrm{kg}^{-1}$; ANOVA, $P<0.001$ ). Aflatoxin levels in smut galls were lower than in the kernels of smut-free control corn (19.9 versus $43.7 \mu \mathrm{g} \mathrm{kg}^{-1}$ for all years combined; ANOVA, $P<0.01)$. Bt genotype, either alone or

Table 1. Incidence of common-smut-affected ears in Bt and non-Bt corn planted in no-till or tilled field trials in Mississippi from 2006 through 2009

\begin{tabular}{lcccc}
\hline & & & \multicolumn{2}{c}{ Infected ears $(\%)^{\mathbf{z}}$} \\
\cline { 3 - 5 } Year & Tillage & $\boldsymbol{P r}>\boldsymbol{F}$ & Bt corn & Non-Bt corn \\
\hline 2006 & No-till plots & 5.8 & 18.1 & 16.5 \\
2007 & No-till plots & 5.1 & 4.6 & 2.6 \\
2008 & No-till plots & 1.5 & 4.0 & 3.6 \\
2008 & Tilled plots & 1.1 & 3.3 & 2.9 \\
2009 & No-till plots & 0.7 & 2.8 & 2.6 \\
2009 & Tilled plots & 0.5 & 4.8 & 2.8 \\
\hline
\end{tabular}

${ }^{2}$ No significant difference $(P<0.05)$ was observed between means in $\mathrm{Bt}$ or non-Bt corn. Percent incidence of ears with common smut was determined on 100 plants in two center rows of the growth plots. 
interacting with tillage or year, had no significant effect on the aflatoxin concentration observed in corn kernels.

In order to determine whether high aflatoxin content of asymptomatic kernels of smutted corn ears reflected a higher incidence of A. flavus infection, we determined the levels of culturable A. flavus propagules in smut galls and asymptomatic kernels of smutted ears and smut-free kernels of control ears during several years of the study (Table 3). The numbers of propagules of A. flavus were consistently greater in the asymptomatic kernels of smutted corn ears than in asymptomatic kernels of smut-free control corn ears. In 2007 and 2008, when A. flavus propagules were determined in the smut galls, the incidence of $A$. flavus propagules in galls was similar to that in the kernels of smut-free control corn ears.

Similar to the case with aflatoxin levels, fumonisin levels were found to vary significantly from year to year but were consistently much higher in the asymptomatic kernels of smutted ears than in smut galls or in the kernels of apparently smut-free ears from the same plots, which were used as controls in each of the years studied (Table 4). Total fumonisin levels in asymptomatic kernels of smutted ears for all years combined was 5.2-fold higher (130 versus
$24.9 \mathrm{mg} \mathrm{kg}^{-1}$ ) than in kernels harvested from asymptomatic control ears (range $=1.5$ - to 47 -fold higher; ANOVA, $P<0.001$ ). The total fumonisin level in asymptomatic kernels of smutted ears for all years combined was 4.0-fold higher (range $=2.6$ - to 6.7-fold higher) than in smut galls (130 versus $32.8 \mathrm{mg} \mathrm{kg}^{-1}$; ANOVA, $P<0.001)$. Fumonisin levels in smut galls were marginally higher than in the kernels of asymptomatic control corn for all years combined ( 32.8 versus $24.9 \mathrm{mg} \mathrm{kg}^{-1}$ ) but the difference was not significant (Table 4). The differences were significant (ANOVA, $P<$ 0.001) for 2007 no-till and 2008 conventional till but not for all years combined, for 2008 no-till, or for 2009 no-till. Fumonisin levels were significantly lower in smut galls than in uninfected kernels of control ears for 2009 conventional till (ANOVA, $P<0.001$ ). In four of the six data sets, there was no effect of Bt genotype on fumonisin concentration. Statistical analysis using Fisher's LSD indicated that, in four of the six data sets, there was no effect of Bt genotype on fumonisin concentration but there was a significant interaction of Bt genotype and sample in 2008 in no-till plots and in corn harvested from no-till plots in 2009 (Table 5). Also, significantly more fumonisin was observed in asymptomatic kernels of

Table 2. Effect of smut infection on total aflatoxin contamination of asymptomatic kernels of smutted corn ears

\begin{tabular}{|c|c|c|c|c|c|c|c|}
\hline \multirow[b]{2}{*}{ Kernel type $^{\mathrm{z}}$} & \multicolumn{7}{|c|}{ Total aflatoxin content $\left(\mu \mathrm{g} \mathrm{kg}^{-1}\right)^{\mathrm{y}}$} \\
\hline & 2006 No-till & 2007 No-till & 2008 No-till & 2008 Conventional till & 2009 No-till & 2008 Conventional till & All years \\
\hline $\begin{array}{l}\text { Asym kernels of } \\
\text { Control ears }\end{array}$ & $54.2 \pm 21 \mathrm{~b}$ & $21.0 \pm 9.6 \mathrm{~b}$ & $46.0 \pm 20.5 b$ & $4.2 \pm 1.6 \mathrm{c}$ & $106 \pm 28.5 b$ & $24.0 \pm 8.4 \mathrm{~b}$ & $43.7 \pm 7.8 \mathrm{c}$ \\
\hline Smutted ears & $215 \pm 32 \mathrm{a}$ & $1165 \pm 310 \mathrm{a}$ & $4388 \pm 346 a$ & $4501 \pm 239 \mathrm{a}$ & $1630 \pm 398 \mathrm{a}$ & $1058 \pm 353 \mathrm{a}$ & $1970 \pm 163 \mathrm{a}$ \\
\hline Smut galls & ND & $2.45 \pm 0.48 \mathrm{c}$ & $56.5 \pm 7.5 \mathrm{~b}$ & $38.5 \pm 2.5 \mathrm{~b}$ & $6.7 \pm 1.2 \mathrm{c}$ & $4.1 \pm 0.4 \mathrm{c}$ & $19.9 \pm 2.2 b$ \\
\hline
\end{tabular}

Table 3. Effect of smut infection of corn ears on Aspergillus flavus contamination levels in asymptomatic kernels and smut galls collected from no-till field trials in Mississippi from 2006 to $2008^{z}$

\begin{tabular}{|c|c|c|c|c|c|}
\hline \multirow[b]{2}{*}{ Year } & \multicolumn{3}{|c|}{ A. flavus propagules $\left(\log _{10} \mathrm{CFU} \mathrm{g}^{-1}\right)$ recovered from } & \multirow[b]{2}{*}{ LSD } & \multirow[b]{2}{*}{$\operatorname{Pr}>\boldsymbol{F}$} \\
\hline & Smut-free control ears & Asymptomatic kernels of smutted ears & Smut galls & & \\
\hline 2006 & $3.40 \mathrm{~b}$ & $6.45 \mathrm{a}$ & ND & 0.26 & $<0.001$ \\
\hline 2007 & $2.91 \mathrm{~b}$ & $3.40 \mathrm{a}$ & $3.50 \mathrm{a}$ & 0.53 & 0.069 \\
\hline 2008 & $4.72 \mathrm{~b}$ & $7.48 \mathrm{a}$ & $7.47 \mathrm{a}$ & 0.19 & $<0.001$ \\
\hline
\end{tabular}

${ }^{\mathrm{z}} \mathrm{LSD}=$ least significant difference and $\mathrm{ND}=$ not determined. Means followed by the same letter within a column do not differ significantly $(P<0.05)$.

Table 4. Effect of smut infection on total fumonisin contamination of asymptomatic kernels of smutted corn ears

\begin{tabular}{lccccccc}
\hline & \multicolumn{5}{c}{ Total fumonisin content (mg kg-1) } \\
\cline { 2 - 7 } Kernel type $^{\mathbf{z}}$ & 2006 No-till & $\mathbf{2 0 0 7}$ No-till & $\mathbf{2 0 0 8}$ No-till & 2008 Conventional till & 2009 No-till & 2008 Conventional till & All years \\
\hline Asym kernels of & & & & & & & \\
$\quad$ Smut-free control ears & $8.63 \pm 1.06 \mathrm{~b}$ & $4.21 \pm 0.65 \mathrm{c}$ & $33.7 \pm 17.3 \mathrm{a}$ & $4.44 \pm 1.55 \mathrm{a}$ & $42.1 \pm 4.1 \mathrm{~b}$ & $32.5 \pm 1.8 \mathrm{~b}$ & $24.9 \pm 4.1 \mathrm{~b}$ \\
$\quad$ Smutted ears & $213 \pm 33 \mathrm{a}$ & $198 \pm 13 \mathrm{a}$ & $56.7 \pm 5.2 \mathrm{a}$ & $78.0 \pm 12.2 \mathrm{a}$ & $125 \pm 10 \mathrm{a}$ & $49.4 \pm 6.1 \mathrm{a}$ & $130 \pm 10 \mathrm{a}$ \\
Smut galls & $\mathrm{ND}$ & $69.4 \pm 3.5 \mathrm{~b}$ & $18.3 \pm 1.9 \mathrm{~b}$ & $11.6 \pm 1.0 \mathrm{~b}$ & $38.8 \pm 4.1 \mathrm{~b}$ & $18.7 \pm 1.2 \mathrm{c}$ & $32.8 \pm 2.1 \mathrm{~b}$ \\
\hline
\end{tabular}

y Data are shown as means \pm standard error. ND $=$ not determined. Means followed by the same letter within a column do not differ significantly $(P<0.05)$.

${ }^{\mathrm{z}}$ Asym $=$ asymptomatic.

Table 5. Effect of corn Bt genotype and type of tillage on total fumonisin contamination of asymptomatic kernels of smutted corn ears

\begin{tabular}{lccccccc}
\hline & \multicolumn{5}{c}{ Total fumonisin content $\left(\mathbf{m g ~ k g}^{-\mathbf{1}}\right)^{\mathbf{z}}$} \\
\cline { 2 - 7 } Corn genotype & $\mathbf{2 0 0 6}$ No-till & $\mathbf{2 0 0 7}$ No-till & $\mathbf{2 0 0 8}$ No-till & 2008 Conventional till & $\mathbf{2 0 0 9}$ No-till & 2008 Conventional till & All years \\
\hline $\mathrm{Bt}$ & $197 \pm 58 \mathrm{a}$ & $221 \pm 21 \mathrm{a}$ & $39.6 \pm 3.9 \mathrm{~b}$ & $100 \pm 22 \mathrm{a}$ & $137 \pm 16 \mathrm{a}$ & $46.4 \pm 9.2 \mathrm{a}$ & $128 \pm 17$ a \\
Non-Bt & $232 \pm 27 \mathrm{a}$ & $187 \pm 16 \mathrm{a}$ & $73.7 \pm 7.4 \mathrm{a}$ & $56.0 \pm 9.1 \mathrm{a}$ & $113 \pm 12 \mathrm{a}$ & $52.5 \pm 8.4 \mathrm{a}$ & $135 \pm 10 \mathrm{a}$ \\
\hline
\end{tabular}

${ }^{\mathrm{z}}$ Means followed by the same letter within a column do not differ significantly by analysis of variance (a indicates $P<0.05$ and $\mathrm{b}$ indicates $P<0.01$ ). 
smutted non-Bt ears compared with asymptomatic kernels from smutted Bt corn.

In order to investigate a possible role of insect vectors in transmitting the fungal infections that resulted in production of high mycotoxin levels in asymptomatic kernels of smutted ears, the levels of aflatoxins (Table 6) and of fumonisins (Table 5) were compared in asymptomatic kernels of smutted ears harvested from (i) transgenic corn hybrids expressing $B$. thuringiensis $C r y$ insecticidal proteins (34B24Bt) and from (ii) a near-isogenic hybrid not expressing the gene (34B23). Overall aflatoxin levels in Bt corn were not significantly different (ANOVA, $P=0.406$ ) from aflatoxin levels in nonBt corn for all years combined. Significant differences were observed in some individual years but they did not consistently favor Bt or non-Bt corn. A similar lack of significant differences (ANOVA, $P=0.725$ ) was observed for fumonisin levels (Table 5), with only one crop (2008, no-till) exhibiting a significant difference between Bt and non-Bt corn.

In previously reported studies on the same field, Abbas et al. (1), in work that has been confirmed by many other laboratories, demonstrated that the plant residues left on the surface of no-till fields contained very high levels of fungi, which could result in dust particles from no-till fields carrying higher levels of fungi than dust particles from conventional till fields. The levels of aflatoxins (Table 6) and fumonisins (Table 5) were compared in asymptomatic kernels of smutted ears harvested from plots using (i) conventional till agriculture and (ii) no-till agriculture as an approach to investigating a possible role of dust-borne fungi in establishing the fungal infections that resulted in production of high mycotoxin levels in asymptomatic kernels of smutted ears. There was no significant difference in aflatoxin levels between conventional till and no-till corn for both years with either Bt or non-Bt corn (ANOVA, $P>0.05)$. However, there were significantly higher fumonisin levels in no-till than in conventional till corn for both years combined (ANOVA, $P<0.01)$ and for $2009(P<0.001)$ but not for 2008 $(P=0.11)$.

\section{Discussion}

In 4 years of Mississippi field studies, grain collected from ears infected with smut consistently had elevated concentrations of both aflatoxins and fumonisins. There are three possible hypotheses to explain this occurrence: (i) a corn ear that gets infected by U. maydis is intrinsically weaker and more susceptible to infection by Aspergillus spp., Fusarium spp., additional U. maydis, and possibly other fungi; (ii) when corn is infected by $U$. maydis, gall formation causes a loss of husk integrity that can allow access by fungi to other kernels not infected by U. maydis, including Aspergillus spp., Fusarium, spp., and possibly others carried on vectors such as dust particles or small insects; or (iii) infection by $U$. maydis alters the endophyte community associated with corn tissue. The first hypothesis, that weakened corn is predisposed to infection by U. maydis, has been supported by studies (17) showing that a greater incidence of smut occurs when corn is under water stress during the grainfilling stage of ontogeny. Likewise, the greatest incidence of aflatoxin accumulation occurs when corn is also undergoing water and heat stress during the grain-filling stage $(2,4)$. Considering the second hypothesis, the infection of corn kernels by U. maydis occurs through a series of hydrolytic processes, including pectinases, cellulases, and xylanases $(7,10)$. The role of hydrolytic enzymes in the infection of plants has been established (18). Hydrolytic enzymes secreted to breach host defenses in the initial infection process may diffuse to other kernels in the ear, facilitating secondary infections. The expression of specific proteases has been correlated with the ability to produce high concentrations of aflatoxin in their infected hosts $(6,11)$, as well as the cell-wall-degrading pectinases (18). In addition, the infection of corn by $U$. maydis results in a reallocation of organic nitrogen pools elsewhere in the plant, so that greater amounts of certain amino acids such as arginine and glutamine are available to support the growth of fungi elsewhere in the ear (15). Regarding the third hypothesis of an altered endophyte community, Pan et al. (20) demonstrated that $U$. maydis infection of corn had significant effects on the endophyte community composition, including toxigenic Fusarium spp.

The observations that mycotoxin levels are much higher in asymptomatic kernels of smutted ears than in either smut galls or asymptomatic controls is consistent with a model in which $U$ maydis infects corn kernels before substantial mycotoxin production by other fungi has occurred and in which the $U$ maydis infection process prevents any significant superinfection by other fungi and subsequent production of their mycotoxins. However, the loss of husk integrity resulting from $U$ maydis gall formation renders adjacent asymptomatic kernels in smutted ears susceptible to attack by vector-borne fungi. The observed results are consistent with Btsusceptible insects not playing a significant role in vectoring enhanced infection of the kernels of smutted ears by aflatoxigenic and fumonisin-producing fungi. However, the loss of husk integrity allows direct access to kernels by small insects (e.g., thrips) that cannot penetrate the intact husk and it facilitates access by larger insects (e.g., corn earworm, nitidulid beetles, and fungus beetles) without requiring consumption of plant tissue before exposing kernels to vectored fungi. A preliminary evaluation of A. flavus vectored by insects (fungus beetle, corn ear worm, European corn borer, fall armyworm, and southwestern corn borer) in smutted ears in this study indicated aflatoxigenicity percentages comparable with those reported (3) for corn plant tissues (unpublished results). The observations of higher fumonisin levels in asymptomatic kernels of smutted ears with notill agriculture than with conventional-till agriculture is consistent with a significant role for dust-borne fungi in the contamination of adjacent kernels of smutted ears.

Aflatoxin levels in galls in 2008 were above acceptable food safety levels (Table 2), indicating the need to monitor aflatoxin in corn smut intended for human consumption. Similarly, fumonisin contamination of galls was above food safety guidelines recommended by the Food and Drug Administration of 2 to $4 \mathrm{mg} \mathrm{kg}^{-1}$ in all years (Table 4), indicating the need to monitor fumonisin levels in corn smut intended for human consumption. The observations presented in this study do not necessarily raise particular food safety issues with $U$. maydis galls themselves, given that the mycotoxin levels observed in them were similar to those in kernels of smut-free control ears, and that smut galls are normally harvested earlier than kernel corn. However, $U$. maydis infection causes altered host anatomy, loss of husk integrity, breaches in the kernel pericarp, and opening adjacent tissue to opportunistic colonization by toxigenic fungi, all of which substantially affect the safety of coproduced kernels. Given that mycotoxins such as aflatoxin and fumonisins are produced prior to maturity, when declining moisture levels reduce fungal activity, the observations presented here of elevated mycotoxins in coproduced kernels at maturity indicate a potential hazard, and support the need for testing before they can be considered safe for consumption.

Table 6. Effect of corn Bt genotype and type of tillage on total aflatoxin contamination of asymptomatic kernels of smutted corn ears

\begin{tabular}{lcrrrrrr}
\hline & \multicolumn{5}{c}{ Total aflatoxin content $\left(\boldsymbol{\mu g} \mathbf{~ k g}^{-\mathbf{1}}\right)^{\mathbf{z}}$} \\
\cline { 2 - 7 } Corn genotype & 2006 No-till & 2007 No-till & 2008 No-till & 2008 Conventional till & 2009 No-till & 2008 Conventional till & All years \\
\hline $\mathrm{Bt}$ & $5,602 \pm 3,192 \mathrm{a}$ & $229 \pm 100 \mathrm{c}$ & $5,058 \pm 476 \mathrm{a}$ & $4,321 \pm 274 \mathrm{a}$ & $788 \pm 189 \mathrm{~b}$ & $636 \pm 158 \mathrm{a}$ & $3,152 \pm 857 \mathrm{a}$ \\
$\mathrm{Non}-\mathrm{Bt}$ & $2,211 \pm 780 \mathrm{a}$ & $2,005 \pm 474 \mathrm{a}$ & $3,566 \pm 425 \mathrm{~b}$ & $4,652 \pm 379 \mathrm{a}$ & $2,382 \pm 704 \mathrm{a}$ & $1,461 \pm 658 \mathrm{a}$ & $2,708 \pm 288 \mathrm{a}$ \\
\hline
\end{tabular}

${ }^{\mathrm{z}}$ Means followed by the same letter within a column do not differ significantly by analysis of variance (a indicates no significant differences, $\mathrm{b}$ indicates $P<0.05$, and $\mathrm{c}$ indicates $P<0.01$ ). 


\section{Literature Cited}

1. Abbas, H. K., Wilkinson, J. R., Zablotowicz, R. M., Accinelli, C., Abel, C. A., Bruns, H. A., and Weaver, M. A. 2009. Ecology of Aspergillus flavus, regulation of aflatoxin production and management strategies to reduce aflatoxin contamination of corn. Toxin Rev. 28:142-153.

2. Abbas, H. K., Accinelli, C., Zablotowicz, R. M., Abel, C. A., Bruns, H. A., Dong, Y., and Shier, W. T. 2008. Dynamics of mycotoxin and Aspergillus flavus levels in aging Bt and non-Bt corn residues under Mississippi no-till conditions. J. Agric. Food Chem. 56:7578-7585.

3. Abbas, H. K., Shier, W. T., and Cartwright, R. D. 2007. Effect of temperature, rainfall, and planting date on aflatoxin and fumonisin contamination in commercial Bt and non-Bt corn hybrids in Arkansas. Phytoprotection 88:41-50.

4. Abbas, H. K., Williams, W. P., Windham, G. L., Pringle, H. C., Xie, W., and Shier, W. T. 2002. Aflatoxin and fumonisin contamination of commercial corn (Zea mays) hybrids in Mississippi. J. Agric. Food Chem. 50:5246-5254.

5. Abbas, H. K., Zablotowicz, R. M., Weaver, M. A., Horn, B. W., Xie, W., and Shier, W. T. 2004. Comparison of cultural and analytical methods for determination of aflatoxin production by Mississippi Delta Aspergillus isolates. Can. J. Microbiol. 50:193-199.

6. Asis, R., Muller, V., Barrionuevo, D. L., Arajuvo, S. A., and Aldao, M. A. 2009. Analysis of protease activity in Aspergillus flavus and Aspergillus parasiticus on peanut seed infection and aflatoxin contamination. Eur. J. Plant Pathol. 124:391-403.

7. Brefort, T., Doehlemann, G., Mendoza-Mendoza, A., Reissmann, S., Djamei, A., and Kallmann, R. 2009. Ustilago maydis as a pathogen. Annu. Rev. Phytopathol. 47:423-445.

8. Bruns, H. A., and Abbas, H. K. 2005. Responses of short-season corn hybrids to a humid sub-tropical environment. Agron. J. 97:446-451.

9. Bruns, H. A., and Abbas, H. K. 2006. Effects of glufosinate-ammonium and urea on aflatoxin and fumonisin levels in corn. Online publication. Plant Health Prog.

10. Cano-Canchola, C., Acevedo, L., Ponce-Noyla, P., Flores-Martinez, A., Flores-Carre, F. A., and Leal-Morales, C. A. 2000. Induction of lytic enzymes by the interaction of Ustilago maydis with Zea mays tissue. Fungal Genet. Biol. 29:145-151.

11. Chen, Z. Y., Brown, R. L., Cary, R. W., Damann, K. E., and Cleveland, T. E. 2009. Characterization of an Aspergillus flavus alkaline protease and its role in the infection of maize kernels. Toxin Rev. 28:187-197.

12. Council for Agriculture Science and Technology (CAST). 2003. Mycotoxins: Risks in Plant, Animal, and Human Systems. Task Force Rep. 139. CAST, Ames, IA.

13. Diener, U. L., Cole, R. J., Sanders, T. H., Payne, G. A., Lee, L. S., and Klich, M. A. 1987. Epidemiology of aflatoxin formation by Aspergillus flavus. Annu. Rev. Phytopathol. 25:249-270.
14. Dowd, P. F. 2000. Indirect reduction of ear molds and associated mycotoxins in Bacillus thuringiensis in corn under controlled and open field conditions: Utility and limitations. J. Econ. Entomol. 93:1669-1679.

15. Horst, R. J., Doehlemann, G., Wahl, R., Hoffmann, J., Schmiedl, A., Kahmann, R., Kämper, J., Sonnewald, U., and Voll, L. M. 2010. Ustilago maydis infection strongly alters organic nitrogen allocation in maize and stimulates productivity of systemic source leaves. Plant Physiol. 152:293-308.

16. King, E. D., Bassi, A. B., Ross, D. C., and Druebbisch, B. 2011. An industry perspective on the use of atoxigenic strains of Aspergillus flavus as biological control agents and the significance of cyclopiazonic acid. Toxin Rev. 30:33-41.

17. Kostandi, S. F., and Soliman, M. F. 1998. Water stress and N fertilization effects on yield and smut disease incidence in corn (Zea mays L.). J. Agron. Crop Sci. 180:151-157.

18. Mellon, J. E., Cotty, P. J., and Dowd, M. K. 2007. Aspergillus flavus hydrolases: Their role in pathogenesis and substrate utilization. Appl. Microbiol. Biotechnol. 77:497-504.

19. National Toxicology Program (NTP). 2001. Toxicology and Carcinogenesis Studies of Fumonisin B1 in F344/N Rats and B6C3F1 Mice (Feed Studies). Department of Health \& Human Services, Public Health Service, NTP, Central Data Management, Research Triangle Park, NC.

20. Pan, J. J., Baumgartner, A. M., and May, G. 2008. Effects of host plant environment and Ustilago maydis infection on the fungal endophyte community of maize (Zea mays). New Phytol. 178:147-156.

21. Payne, G. A. 1992. Aflatoxin in maize. Crit. Rev. Plant Sci. 10:423-440.

22. Potkański, A., Grajewski, J., Twarużek, M., Selwet, M., Miklaszewska, B., Błajet-Kosicka, A., Szumacher-Strabel, M., Cieślak, A., and RaczkowskaWerwińska, K. 2010. Chemical composition, fungal microflora, and mycotoxin content in maize silage infected by smut (Ustilago maydis) and the effect of biological and chemical additives on silage aerobic stability. J. Anim. Feed Sci. 19:132-142.

23. Robens, J., and Cardwell, K. 2003. The costs of mycotoxin management to the USA: Management of aflatoxins in the United States. J. Toxicol. Toxin Rev. 22:139-152.

24. Saxton, A. M. 1998. A macro for converting mean separation output to letter groupings in Proc Mixed. Pages 1243-1246 in: Proc. 23rd SAS User Group Int. Conf. SAS Institute, Inc. Cary, NC.

25. Shurtleff, M. C. 1980. Compendium of Corn Diseases, 2nd ed. American Phytopathological Society, St. Paul, MN.

26. Statistical Analysis Systems. 2001. SAS User's Guide, Version 8.1. SAS Institute, Cary, NC.

27. Uribe, M. O. 2009. In Mexico, tar-like fungus considered delicacy. Online publication. www.npr.org/templates/story/story.php?storyId=111789560 